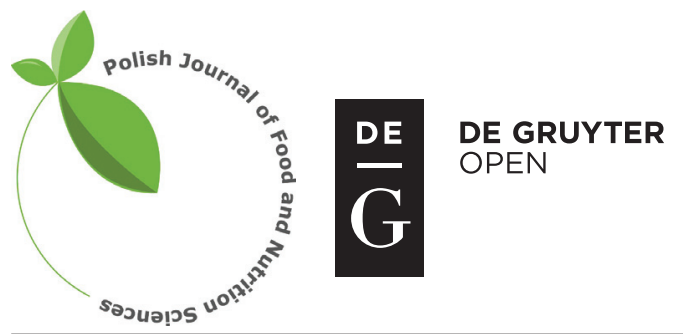

Pol. J. Food Nutr. Sci., 2017, Vol. 67, No. 3, pp. 201-209

DOI: $10.1515 /$ pjfns-2016-0026 http://journal.pan.olsztyn.pl

Original research article

Section: Food Quality and Functionality

\title{
Multivariate Study of Inulin Addition on the Quality of Sponge Cakes
}

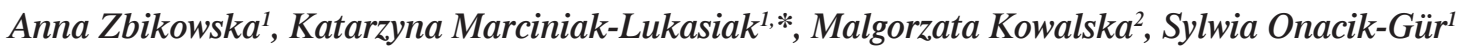 \\ ${ }^{1}$ Division of Fats \& Oils and Food Concentrates Technology, Faculty of Food Sciences, \\ Warsaw University of Life Sciences, Street Nowoursynowska 159 C, 02-776 Warsaw, Poland \\ ${ }^{2}$ Department of Chemistry, Faculty of Material Science, Technology and Design, \\ Kazimierz Pulaski University of Technology and Humanities, Street Chrobrego 27, 26-600 Radom, Poland
}

Key words: biscuits, inulin, texture, rheology

The aim of the study was to determine the possibility of reducing fat content in fatty sponge-cake products by addition of inulin. $200 \mathrm{~g} / \mathrm{kg}, 440 \mathrm{~g} / \mathrm{kg}$, $680 \mathrm{~g} / \mathrm{kg}$ and $100 \%$ of fat was substituted with $20 \mathrm{~g} / \mathrm{kg}, 35 \mathrm{~g} / \mathrm{kg}, 50 \mathrm{~g} / \mathrm{kg}$, and $62.5 \mathrm{~g} / \mathrm{kg}$ of inulin, respectively. The authors used two types of fat: with low and high content of trans isomers - containing $2.1 \mathrm{~g} / \mathrm{kg}$ and $511.2 \mathrm{~g} / \mathrm{kg}$ of fatty acid methyl esters (FAME), respectively. An analysis of crumb quality and the evaluation of sensory discriminants were undertaken.

It was demonstrated that it was possible to substitute fat with inulin in fatty sponge-cake products. However, in the case of fat with a high content of trans fatty acids (TFA), its substitution even with higher amounts of inulin had a smaller impact on the qualitative parameters of products than in the case of fat without TFA.

Substitution of fats with inulin allows for eliminating dangerous TFA, reduces energetic value of food products, and simultaneously enriches them with nutritionally-valuable oligosaccharides. Furthermore, products without the addition of inulin-based fat can be an alternative to conventional fatty sponge-cake products and a factor that supports prevention in many food-related and other diseases.

\section{INTRODUCTION}

Fat is the most energetic food component and can contribute to the global, well-known disorders such as obesity, atherosclerosis, hypertension, coronary heart disease, diabetes, and cancer [Hennelly et al., 2006]. Obesity is one of the most dangerous civilization diseases, which contributes to the development of many diet-related conditions. Based on research conducted by the $\mathrm{WHO}$, obesity has afflicted more than 700 million adults worldwide [WHO, 2010]. Particularly negative is the fact of the growing obesity among children [James, 2008; De Onis et al., 2010]. Although fats consist of polyunsaturated fatty acids (PUFAs) that have a positive impact on human organisms [Marciniak-Lukasiak, 2011], bakery shortenings are characterized by a high content of saturated fatty acids (SFAs) and can be a source of trans fatty acids (TFAs). Many reports have indicated that high levels of TFAs in diet result in adverse effects on both low-density lipoprotein and high-density lipoprotein cholesterol [Bendsen et al., 2011; Żbikowska, 2010].

Fats are also an important component of pastry goods, especially fatty sponge-cakes, as they hold the air in raw dough, thereby increasing its volume and creating a porous

\footnotetext{
* Corresponding Author: Tel.: +4822 5937525; Fax: +4822 5937527

E-mail: katarzyna_marciniak_lukasiak@sggw.pl (K. Marciniak-Łukasiak)
}

structure of baked products. They perform other functions, such as the impact on feelings upon eating, product appearance and texture, longer product stability, and are involved in the releasing of aromas [Rutkowska \& Zbikowska, 2010]. Removal of fat from products characterized by the unbeneficial FA profile leads to a reduction of a caloric value and to obtaining health-promoting foods, especially when fat is replaced by dietary fiber.

Recent interest in inulin results from its prebiotic properties. Inulin belongs to long-chain carbohydrates [Blonska et al., 2014] and is not decomposed by human digestive enzymes. However it is a perfect carbon source for health-promoting prebiotic bacteria. Inulin is ranked as a soluble fibre, because it is not hydrolyzed in the human gastrointestinal tract. Moreover, inulin has various functional properties. One of the most important is its fat mimetic property, which is successfully used in the production of mayonnaise, margarine [Cieslak \& Gebusia, 2011], processed meats [Hadorn et al., 2007] or yogurts [Kip et al., 2006]. Inulin was also applied in bread [Filipovic et al., 2010; Morris \& Morris, 2012] and pasta [Brennan, 2004] production.

Food products with inulin in the role of a fat replacer can reduce the risk of obesity and support the process of treatment. Value of NOEL for inulin (No Observed Effect Level) is $30 \mathrm{~g}$ per day [Coussement, 1999]. Based on Grabitske \& Slavin [2009], it can be found that intake of up to $15 \mathrm{~g}$ inulin 
TABLE. 1. Characteristics of fatty acid composition in raw fatty material (\% of FAME - methyl ester of fatty acid).

\begin{tabular}{|c|c|c|c|c|c|c|c|c|c|}
\hline \multirow{3}{*}{ Type of fats } & \multicolumn{9}{|c|}{ Fatty acids } \\
\hline & \multicolumn{3}{|c|}{ SFA } & \multicolumn{2}{|c|}{ TFA } & \multicolumn{2}{|c|}{ MUFA cis } & \multicolumn{2}{|c|}{ PUFA cis } \\
\hline & Total & C16:0 & C18:0 & Total & C18:1t9 & Total & C18:1c9 & Total & $\mathrm{C} 18: 3 \mathrm{ccc}$ \\
\hline AK & 48.43 & 41.89 & 4.72 & 0.21 & - & 40.44 & 38.87 & 10.16 & 0.30 \\
\hline HR & 27.74 & 12.83 & 12.88 & 51.12 & 49.83 & 19.05 & 7.02 & 2.00 & 0.46 \\
\hline
\end{tabular}

SFA - saturated fatty acids, TFA - trans fatty acids, MUFA - monounsaturated fatty acids, PUFA - polyunsaturated fatty acids, AK - bakery fat Akobake, $\mathrm{HR}$ - hydrogenated rapeseed fat.

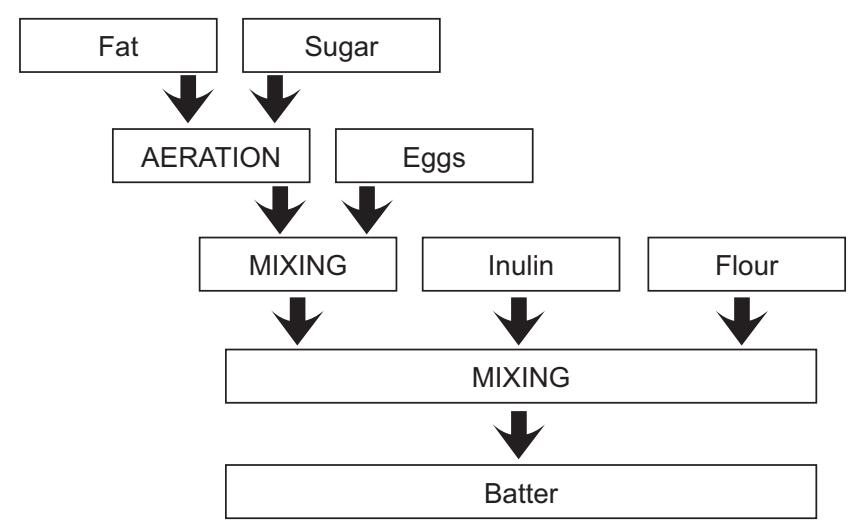

FIGURE 1. Manufacturing process.

per day is well tolerated by adult consumers without the presence of any detrimental gastrointestinal symptoms.

The purpose of the study was to determine the possibility of reducing fat content in fatty sponge-cake products by addition of inulin and to determine its impact on the product quality by applying the principal component analysis (PCA).

\section{MATERIALS AND METHODS}

\section{Materials}

During the experiments, two entirely vegetable fats: bakery fat Akobake (AK) - trans-free fat with trans isomers $(<10 \mathrm{~g} / \mathrm{kg}$ of FAME - Fatty Acid Methyl Esters) - and partially hydrogenated rapeseed fat (HR) with a high content of TFA (about $500 \mathrm{~g} / \mathrm{kg}$ of FAME) (presented in Table 1) were used. Inulin from Orafti Beneo ${ }^{\circledR}$ HPX-Orafti SA, Belgium (inulin content-100\%, DPav $\geq 23$ ) was added in the amount of $20 \mathrm{~g} / \mathrm{kg}, 35 \mathrm{~g} / \mathrm{kg}, 50 \mathrm{~g} / \mathrm{kg}, 62.5 \mathrm{~g} / \mathrm{kg}$ in relation to the total mass of the raw dough. The rest of the recipe consisted of wheat flour type 480 including $320 \mathrm{~g} / \mathrm{kg}$ of wet gluten, sugar powder and fresh eggs purchased at a local food market.

\section{Technology of production and baking of fatty sponge- -cake products}

Recipes for the products analyzed are presented in Table 1 and the manufacturing process is described in Figure 1.

Raw dough was placed in molds of $350 \mathrm{~g}$ and baked at $185^{\circ} \mathrm{C}$ for $45 \mathrm{~min}$ in an electric furnace of Sveba Dahlin, Sweden Fristad DC-32E. Three samples of each pastry were made.

\section{Analysis of fats}

Prior to the analysis, the Gas Chromatography (GC) fat sample was derivatized to fatty acid methyl esters (FAME). $100 \mathrm{mg}$ of the fat extract was dissolved in $10 \mathrm{~mL}$ of hexane, and next $100 \mu \mathrm{L} 2 \mathrm{~N}$ of potassium hydroxide was added.

FA content was analyzed using a gas chromatograph Agilent Technologies 7890A equipped with a FID detector with a capillary Restek 2330 type, $100 \mathrm{~m}, 0.25 \mathrm{~mm}, 0.2 \mu \mathrm{m}$ df column (90\% biscyanopropyl/10\% phenylcyanopropyl). The following parameters of analysis were used: helium as a carrier gas, flow rate $1.2 \mathrm{~mL} / \mathrm{min}$, temp. of injector and detector: $250^{\circ} \mathrm{C}$ and $300^{\circ} \mathrm{C}$, respectively, split ratio 1:50; the temperature program was as follows: $100^{\circ} \mathrm{C}$ for $4 \mathrm{~min}$, increased by $3^{\circ} \mathrm{C} / \mathrm{min}$ to reach $240^{\circ} \mathrm{C}$. Quality (retention time) and quantity (internal normalization) were evaluated using standards of fatty acids methyl esters (Supelco).

\section{Density and porosity}

Batter density and crumb density were determined based on Rahmati et al. [2013] using the following equation:

$$
\mathrm{M}_{\mathrm{s}}=(M / V) \times 1000
$$

where: $\mathrm{M}_{\mathrm{s}}$ - density of batter/ crumb $\left(\mathrm{g} / \mathrm{dm}^{3}\right), M$ - mass of batter/crumb (g), $V$ - volume of batter/ crumb $\left(\mathrm{cm}^{3}\right)$, accordingly.

In addition, average porosity of the crumb was determined using the following formula [Horubalowa, 1983]:

$$
x=(a-b) \times 100 / a
$$

where: $x$ - crumb porosity (\%), $a$ - volume of a cut cube with an intact crumb $\left(50.7 \mathrm{~cm}^{3}\right), b$ - volume of crumb after removal of the porous structure $\left(\mathrm{cm}^{3}\right)$.

The water content was determined $24 \mathrm{~h}$ after baking by drying 5 -g samples at $103 \pm 2^{\circ} \mathrm{C}$ for $3 \mathrm{~h}$.

The final results were calculated as a mean of at least three replicates.

\section{Instrumental analysis of crumb texture}

Textures of the products were analyzed instrumentally using a ZWICK texture analyzer, type 1120 . Tests of cut and double compression have been conducted. 20-mm thick samples were cut using a straight-blade knife with a force of $0.5 \mathrm{~N}$ and the initial moving speed of the operating element was equal to $50 \mathrm{~mm} / \mathrm{min}$. The double compression test consisted of double squeezing of crumb samples $(40 \times 40 \times 40 \mathrm{~mm})$. 
The samples were compressed using a plate until relative compression was equal to $50 \%$.

Hardness (the force necessary to attain a given deformation), cohesiveness (the strength of internal bonds making up the body of a product), elasticity (the rate at which a deformed material returns to its original shape after the deforming force is removed), and chewiness (the energy required to masticate a solid food product to a state ready for swallowing) were determined - the definitions were based on the literature [Surmacka-Szczesniak, 1963].

Crumb texture image was analyzed using a scanning electron microscope by FEJ QUANTA 2000 ESM ENVINRONMENTAL company. Conditions of the analysis were as follows: room temperature, absence of a conductive layer, accelerating voltage $27 \mathrm{kV}$, the detector 'Det LFD', and low vacuum of 130.6 Pa. Photographs were taken at a magnification of $50 \mathrm{x}$.

\section{Energetic value}

Energetic values of the investigated products were determined in reference to a table of energetic (caloric) values of particular components [Kunachowicz, 2005].

\section{Sensory evaluation}

Detailed sensory characteristics of the products were determined by means of quantitative descriptive analysis (QDA) using the analytical procedure described in ISO 13299 standard [ISO, 2003]. A group of 20 trained persons identified discriminants of the samples: appearance, odor, texture, and taste. For the profile analysis, 15 quality discriminants have been selected [Barylko-Pikielna \& Matuszewska, 2009]. The resulting values were converted to numerical values on a scale from 0 (lowest rank) to 10 (highest rank) arbitrary units.

\section{Statistical analysis}

Results for the physical and sensory parameters of the dough were analyzed using principal component analysis with classification (PCA). The coefficient of Pearson correlation between the physical properties of the samples was also calculated. The results were subjected to one-way ANOVA. The Duncan test served to assess the differences be- tween means. The level of $\mathrm{p}>0.05$ was considered significant. The statistical analysis employed Statistica 10.0.

\section{RESULTS}

\section{The effect of inulin addition on quality of the intermediate product}

The substitution of fat characterized by a low content of trans fatty acids (TFA) $(2.1 \mathrm{~g} / \mathrm{kg}$ of FAME) with inulin significantly increased density of the batter. In the case of fat having a high content of TFA (511.2 g/ $\mathrm{kg}$ of FAME), such a significant decrease of intermediate product aeration was not observed. Batter without fat $(-6.25)$ was characterized by best aeration (Table 3 ).

\section{The effect of inulin addition on quality of the crumb and water content in the crumb of fatty sponge-cake products}

The addition of 20 to $62.5 \mathrm{~g} / \mathrm{kg}$ of inulin significantly reduced fat content and energetic value of the obtained products. With a total elimination of fat, the energetic value of fatty sponge-cake products decreased by as much as $900.2 \mathrm{~kJ} / 100 \mathrm{~g}$ of the product (Table 2).

Regarding the substitution of high-TFA fat (HR)with inulin, a lower variation in the quality of crumb products compared to fatty sponge-cake products without TFA (AK) was observed. The largest addition of inulin in the samples containing fat $(50 \mathrm{~g} / \mathrm{kg})$ resulted in an improved quality of crumb products with HR fat. However, in the case of AK substitution, it was found that $20 \mathrm{~g} / \mathrm{kg}$ addition of inulin had a positive effect on the studied physical parameters of the crumb. Fat-free products with $62.5 \mathrm{~g} / \mathrm{kg}$ addition of inulin were characterized by the lowest density and highest porosity (Table 3).

The highest moisture content was observed in the products with the largest additions of inulin (50 and $62.5 \mathrm{~g} / \mathrm{kg}$ ). Even the smallest addition of inulin $(20 \mathrm{~g} / \mathrm{kg})$ increased water content in the products with HR fat by $27 \mathrm{~g} / \mathrm{kg}$, and in the products including AK fat by $17.6 \mathrm{~g} / \mathrm{kg}$ (Table 3 ).

The study involved instrumental measurement of mechanical properties of the crumb and its results were used to evaluate hardness, cohesion, elasticity, and chewiness.

TABLE 2. Recipes of fatty sponge-cake products and their energetic values.

\begin{tabular}{l|c|c|c|c|c|c|c|c|c}
\hline \multirow{2}{*}{ Ingredients (g) } & \multicolumn{9}{c}{ Formulation } \\
\cline { 2 - 10 } & HR 0 & HR 2.0 & HR 3.5 & HR 5.0 & AK 0 * & AK 2.0 & AK 3.5 & AK 5.0 & -6.25 \\
\hline Wheat flour & 281.2 & 303.8 & 320.6 & 337.5 & 281.2 & 303.8 & 320.6 & 337.5 & 351.6 \\
Powder sugar & 281.2 & 303.8 & 320.6 & 337.5 & 281.2 & 303.8 & 320.6 & 337.5 & 351.6 \\
Eggs & 281.2 & 303.8 & 320.6 & 337.5 & 281.2 & 303.8 & 320.6 & 337.5 & 351.6 \\
Fat (**) & 281.2 & 191.2 & 123.8 & 56.2 & 281.2 & 191.2 & 123.8 & 56.2 & 0.0 \\
Inulin & $(100 \%)$ & $(68)$ & $(44 \%)$ & $(20 \%)$ & $(100 \%)$ & $(68 \%)$ & $(44 \%)$ & $(20 \%)$ & $(-)$ \\
Inulin (\%) (in relation & 0 & 22.5 & 39.4 & 56.2 & 0 & 22.5 & 39.4 & 56.2 & 70.3 \\
to 100 g of recipe content) & - & 2.0 & 3.5 & 5.0 & - & 2.0 & 3.5 & 5.0 & 6.25 \\
$\begin{array}{l}\text { Loss in energetic } \\
\text { value (kJ/100 g) }\end{array}$ & 0 & 301.5 & 544.3 & 720.1 & 0 & 301.5 & 544.3 & 720.1 & 900.2 \\
\hline
\end{tabular}

*- control sample '- - fat-free, ${ }^{*}$ - in relation to the amount of fat in the control sample. The products were investigated $24 \mathrm{~h}$ after baking. 
TABLE 3. Physical characteristics of fatty sponge-cake products.

\begin{tabular}{|c|c|c|c|c|c|c|c|c|c|}
\hline Fat addition (\%) & 100 & 68 & 44 & 20 & 100 & 68 & 44 & 20 & 0 \\
\hline Sample & HR 0 & HR 2 & HR 3.5 & HR 5 & AK 0 & AK 2 & AK 3.5 & AK 5 & -6.25 \\
\hline Density of batter $\left(\mathrm{g} / \mathrm{dm}^{3}\right)$ & 1034 & 1020 & 1052 & 1024 & 846.88 & 826 & 942 & 1046 & 738 \\
\hline Crumb density $\left(\mathrm{g} / \mathrm{dm}^{3}\right)$ & $530.08^{\mathrm{bc}}$ & $551.48^{\mathrm{c}}$ & $550.19^{\mathrm{c}}$ & $528.90^{\mathrm{b}}$ & $468.39^{\mathrm{C}}$ & $428.55^{\mathrm{B}}$ & $460.45^{\mathrm{C}}$ & $498.83^{\mathrm{D}}$ & $337.08^{\mathrm{aA}}$ \\
\hline Crumb porosity $(\%)$ & $46.25^{\mathrm{a}}$ & $43.79^{\mathrm{a}}$ & $46.25^{\mathrm{a}}$ & $45.77^{\mathrm{a}}$ & $53.65^{\mathrm{AB}}$ & $57.59^{\mathrm{C}}$ & $55.13^{\mathrm{BC}}$ & $51.70^{\mathrm{A}}$ & $63.76^{\mathrm{bD}}$ \\
\hline Water content $(\%)$ & $16.04^{\mathrm{a}}$ & $18.74^{\mathrm{b}}$ & $18.46^{\mathrm{b}}$ & $21.05^{\mathrm{c}}$ & $16.72^{\mathrm{A}}$ & $18.48^{\text {в }}$ & $19.85^{\mathrm{C}}$ & $20.95^{\mathrm{C}}$ & $20.67^{\mathrm{cC}}$ \\
\hline \multicolumn{10}{|c|}{ Texture analysis } \\
\hline Maximum compressive force $(\mathrm{N})$ & $26.99^{\mathrm{b}}$ & $32.06^{\mathrm{c}}$ & $33.87^{\mathrm{c}}$ & $40.88^{\mathrm{d}}$ & $7.78^{\mathrm{A}}$ & $8.16^{\mathrm{B}}$ & $18.99^{\mathrm{D}}$ & $43.46^{\mathrm{E}}$ & $17.49^{\mathrm{aC}}$ \\
\hline \multicolumn{10}{|c|}{ Double compression test } \\
\hline Cohesion & $0.423^{\mathrm{a}}$ & $0.443^{\mathrm{b}}$ & $0.462^{\mathrm{c}}$ & $0.512^{\mathrm{d}}$ & $0.404^{\mathrm{A}}$ & $0.429^{\mathrm{B}}$ & $0.473^{\mathrm{C}}$ & $0.517^{\mathrm{D}}$ & $0.564^{\mathrm{eE}}$ \\
\hline Elasticity & $0.725^{\mathrm{a}}$ & $0.746^{\mathrm{b}}$ & $0.763^{\mathrm{c}}$ & $0.790^{\mathrm{d}}$ & $0.757^{\mathrm{A}}$ & $0.769^{\mathrm{B}}$ & $0.787^{\mathrm{C}}$ & $0.793^{\mathrm{D}}$ & $0.798^{\mathrm{eE}}$ \\
\hline Hardness (N) & $39.448^{\mathrm{b}}$ & $52.879^{\mathrm{e}}$ & $52.723^{\mathrm{d}}$ & $51.071^{\mathrm{c}}$ & $17.492^{\mathrm{B}}$ & $19.984^{\mathrm{C}}$ & $32.668^{\mathrm{D}}$ & $47.664^{\mathrm{E}}$ & $14.760^{\mathrm{aA}}$ \\
\hline Chewiness (N) & $12.014^{\mathrm{b}}$ & $17.242^{\mathrm{c}}$ & $18.567^{\mathrm{d}}$ & $20.562^{\mathrm{e}}$ & $5.349^{\mathrm{A}}$ & $6.589^{\mathrm{B}}$ & $12.139^{\mathrm{D}}$ & $17.538^{\mathrm{E}}$ & $6.636^{\mathrm{aC}}$ \\
\hline
\end{tabular}

a-e, A-E - capitalized characters in each row mean statistically significant differences at $\mathrm{p} \geq 0.05$.

TABLE 4. Correlation matrix of cookies textural characteristics.

\begin{tabular}{lccccccccc|cc|cc}
\hline & $\mathrm{d}_{\mathrm{d}}$ & $\mathrm{d}_{\mathrm{p}}$ & Porosity & $\mathrm{F}_{\max }$ & Hardness & Cohesion & Elasticity & Chewiness & w\% & $\mathrm{d}_{\mathrm{c}}$ \\
\hline $\mathrm{d}_{\mathrm{d}}$ & 1.000 & 0.947 & -0.895 & 0.887 & 0.978 & 0.016 & -0.259 & 0.941 & 0.169 & 0.864 \\
$\mathrm{~d}_{\mathrm{p}}$ & 0.947 & 1.000 & -0.969 & 0.777 & 0.911 & -0.192 & -0.408 & 0.854 & 0.019 & 0.942 \\
Porosity & -0.895 & -0.969 & 1.000 & -0.703 & -0.895 & 0.312 & 0.520 & -0.803 & 0.093 & -0.977 \\
$\mathrm{~F}_{\max }$ & 0.887 & 0.777 & -0.703 & 1.000 & 0.895 & 0.427 & 0.068 & 0.938 & 0.497 & 0.594 \\
Hardness & 0.977 & 0.911 & -0.895 & 0.895 & 1.000 & 0.056 & -0.205 & 0.970 & 0.238 & 0.853 \\
Cohesion & 0.016 & -0.192 & 0.312 & 0.427 & 0.056 & 1.000 & 0.783 & 0.252 & 0.850 & -0.448 \\
Elasticity & -0.258 & -0.409 & 0.519 & 0.068 & -0.205 & 0.783 & 1.000 & 0.017 & 0.856 & -0.573 \\
Chewiness & 0.941 & 0.854 & -0.804 & 0.938 & 0.970 & 0.252 & 0.017 & 1.000 & 0.452 & 0.742 \\
w\% & 0.169 & 0.0188 & 0.093 & 0.496 & 0.238 & 0.850 & 0.856 & 0.452 & 1.000 & -0.208 \\
$\mathrm{~d}_{\mathrm{c}}$ & 0.864 & 0.942 & -0.978 & 0.594 & 0.853 & -0.447 & -0.573 & 0.742 & -0.208 & 1.000 \\
\hline
\end{tabular}

$\mathrm{d}_{\mathrm{d}}$ - dough density, $\mathrm{d}_{\mathrm{p}}$ - product density, $\mathrm{d}_{\mathrm{c}}-$ crumb density, porosity, $\mathrm{F}_{\max }-$ maximum compressive force, cohesion, elasticity, hardness; chewiness, $\mathrm{w} \%$ - moisture content.

The maximum force required to cut the crumb of samples of fatty sponge-cake products increased in line with the inulin addition. A greater force was required to cut the high-TFA samples (HR). In respect of fat-free products $(62.5 \mathrm{~g} /$ $\mathrm{kg}$ inulin), a statistically significant decrease of its value was noticed compared to the fat-containing products (Table 3).

An increased inulin addition and a simultaneous lower content of fat in the products caused an increase of cohesiveness, elasticity and chewiness of the crumb, regardless of the fat type (Table 3). In the case of the products containing a trans-free fat (AK), smaller growth of cohesiveness was observed: from 0.404 , for samples without inulin, to 0.517 - for the fat-free products (with $50 \mathrm{~g} / \mathrm{kg}$ inulin). With reference to elasticity, a larger variation occurred in the products with fat (HR) having high content of TFA (from 0.725 to 0.790). A larger increase of hardness was observed in the products with AK fat (from
$17.492 \mathrm{~N}$, for products without inulin, to $47.664 \mathrm{~N}$ for products with $50 \mathrm{~g} / \mathrm{kg}$ inulin). The lowest values of hardness and chewiness were found in fat-free products (Table 3 ).

Based on the statistical analysis, it was found that the mechanical properties of products showed a statistically significant $(p=0.05)$ correlation with density of the batter $\left(d_{d}\right)$ and with the crumb of the finished product $\left(\mathrm{d}_{\mathrm{p}}\right)$, as well as with its porosity. Additionally, a strong positive correlation was found between water content, and cohesiveness, and elasticity of the products (Table 4).

The components used to interpret the results were chosen based on Cattell scree criterion. The physical characteristics of cakes were described by two components (PC1 and PC2) that explained $95.36 \%$ of the variability. The first component, explaining $63.64 \%$ of the variability, was associated with $d_{d}$, $d_{p}, d_{c}$, hardness, chewiness, $F_{\text {max }}$ (strongly positively correlat- 
a)

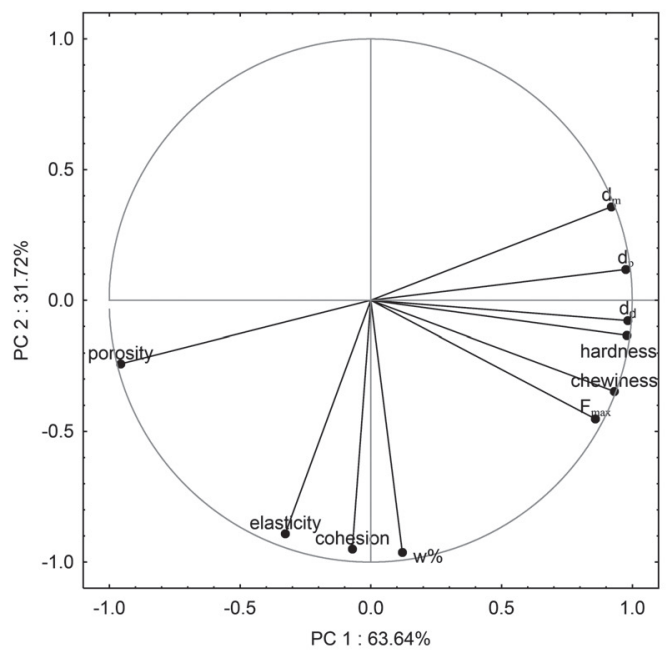

b)

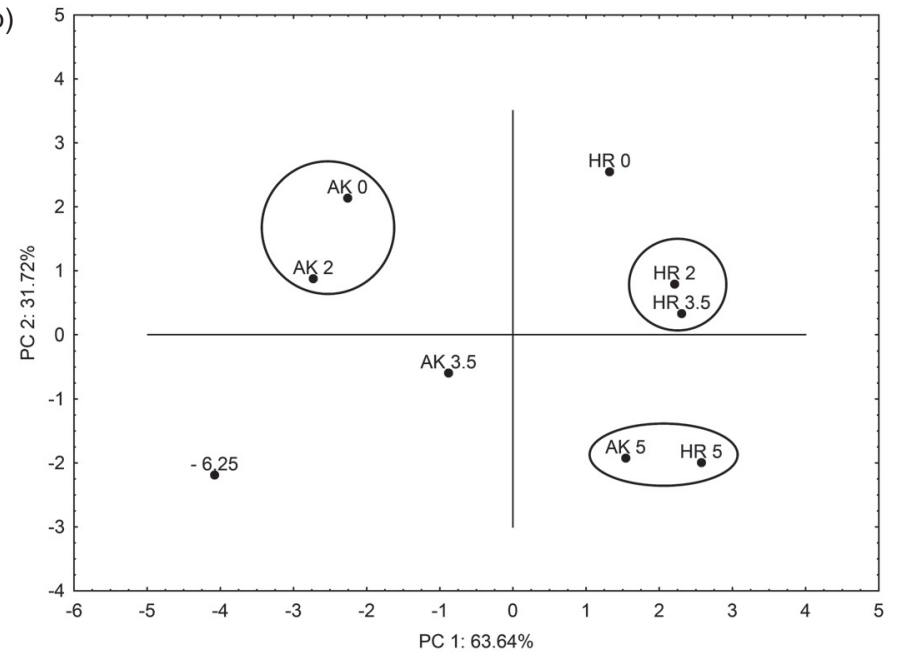

FIGURE 2. Results of the PCA for physical properties of cookies. Variable plot (a) and score plot (b) in the plane of principal components PC1 and PC2 for all samples - description of the labels in Table 3 and 4.

ed), and porosity (strongly negatively correlated). The second component $(31.72 \%)$ was strongly associated with moisture, cohesiveness, and elasticity (Figure 2a).

Taking into consideration the first component (mechanical properties and density), the products including fat with a high content of TFA, regardless of the amount of inulin in the formula, and the product of trans-free fat with $50 \mathrm{~g} / \mathrm{kg}$ of inulin (HR 0, HR 2, HR 3.5 HR 5, AK 5), as well as the samples with the highest content of $\mathrm{AK}(\mathrm{AK} 0, \mathrm{AK} 2)$ were the most similar to each other. Taking into account both the components, on the other hand, the products with 20 and $35 \mathrm{~g} / \mathrm{kg}$ inulin addition containing HR (HR 2 and HR 3.5) and products with $50 \mathrm{~g} / \mathrm{kg}$ of inulin (AK HR 5 and 5) were the most similar. It was demonstrated that the fat-free product $(62.5 \mathrm{~g} / \mathrm{kg}$ of inulin) was not similar to any of the other samples (Figure 2b).
The variable plot (Figure 2b) shows that, with an increasing inulin content in products, location of the samples tended towards the right bottom corner, which is associated with a higher water content, elasticity, cohesion (PC1) and the maximum compressive force and chewiness (PC2).

The microscopic image analysis showed differences in the shape and distribution of the air cells of the analyzed products (Figure 3).

Air cells of products without the inulin addition, as well as those with no added fat $(62.5 \mathrm{~g} / \mathrm{kg}$ inulin), were more evenly distributed across the intersection of the samples compared to products with a reduced fat content. Air cells shown at the intersection of fat-free products (containing $62.5 \mathrm{~g} / \mathrm{kg}$ inulin) had more regular shapes (similar to a circle) than the samples without inulin (Figure 3).

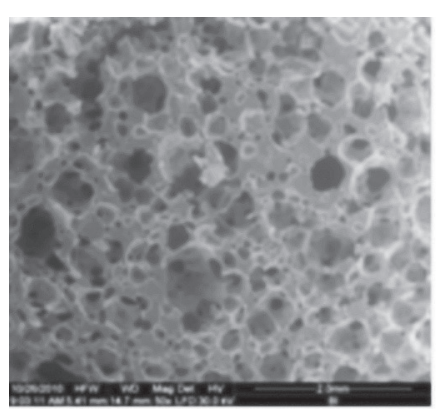

I)

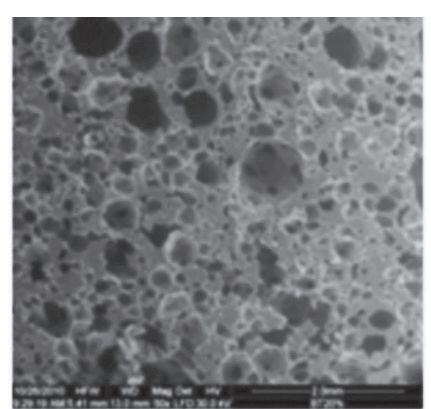

II)

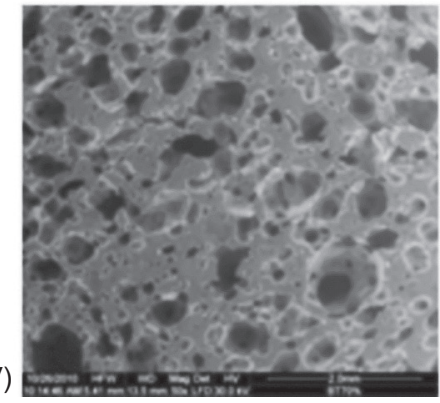

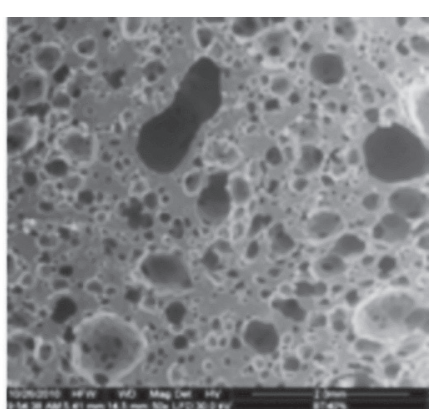

III)

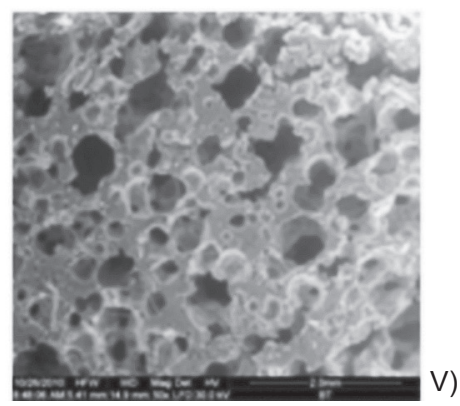

FIGURE 3. Microscopic photo of the crumb of fatty sponge-cake products. Decription: I - formula AK 0; II - formula AK 2.0; III - formula AK 3.5; $\mathrm{IV}$ - formula AK 5.0; and V - formula - 6.25. 
TABLE 5. Discriminants of sensory evaluation of fatty sponge-cake products.

\begin{tabular}{|c|c|c|c|c|c|c|c|c|c|c|}
\hline \multicolumn{2}{|c|}{ Fat addition (\%) } & 100 & 68 & 44 & 20 & 100 & 68 & 44 & 20 & 0 \\
\hline \multicolumn{2}{|c|}{$\begin{array}{ll}\text { Sample } \\
\text { Discriminant }\end{array}$} & HR 0 & HR2.0 & HR 3.5 & HR 5.0 & AK 0 & AK 2 & AK3.5 & AK 5.0 & -6.25 \\
\hline \multirow{4}{*}{$\frac{\overrightarrow{0}}{0}$} & Typical & $46^{\mathrm{ab}}$ & $44^{\mathrm{a}}$ & $50^{\mathrm{cd}}$ & $49^{\mathrm{bc}}$ & $53^{\mathrm{de}}$ & $56^{\mathrm{ef}}$ & $54^{\mathrm{e}}$ & $48^{\mathrm{bc}}$ & $58^{\mathrm{f}}$ \\
\hline & Foreign & $12^{\mathrm{bc}}$ & $13^{\mathrm{c}}$ & $9^{\mathrm{ab}}$ & $7^{\mathrm{a}}$ & $17^{\mathrm{d}}$ & $14^{\mathrm{cd}}$ & $12^{\mathrm{bc}}$ & $8^{\mathrm{a}}$ & $8^{\mathrm{a}}$ \\
\hline & Flour & $25^{\mathrm{a}}$ & $22^{\mathrm{a}}$ & $25^{\mathrm{a}}$ & $25^{\mathrm{a}}$ & $23^{\mathrm{a}}$ & $25^{\mathrm{a}}$ & $25^{\mathrm{a}}$ & $22^{\mathrm{a}}$ & $23^{\mathrm{a}}$ \\
\hline & Fatty & $45^{\mathrm{d}}$ & $34^{\mathrm{bc}}$ & $36^{\mathrm{c}}$ & $35^{\mathrm{c}}$ & $48^{\mathrm{d}}$ & $46^{\mathrm{d}}$ & $45^{\mathrm{d}}$ & $28^{\mathrm{a}}$ & $32^{\mathrm{b}}$ \\
\hline \multirow{2}{*}{ 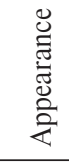 } & Color & $25^{\mathrm{a}}$ & $28^{\mathrm{a}}$ & $38^{\mathrm{b}}$ & $50^{\mathrm{d}}$ & $63^{\mathrm{f}}$ & $57^{e}$ & $45^{\mathrm{c}}$ & $46^{\mathrm{c}}$ & $52^{\mathrm{d}}$ \\
\hline & $\begin{array}{l}\text { Homogeneity } \\
\text { of crumb } \\
\text { structure }\end{array}$ & $43^{d}$ & $20^{\mathrm{a}}$ & $33^{\mathrm{c}}$ & $27^{\mathrm{b}}$ & $72^{\mathrm{g}}$ & $67^{\mathrm{f}}$ & $43^{\mathrm{d}}$ & $42^{\mathrm{d}}$ & $57^{e}$ \\
\hline \multirow{5}{*}{ 氖 } & Porosity & $41^{\mathrm{bc}}$ & $44^{\mathrm{cd}}$ & $44^{\mathrm{cd}}$ & $42^{c}$ & $47^{\mathrm{de}}$ & $48^{e}$ & $41^{\mathrm{bc}}$ & $35^{\mathrm{a}}$ & $38^{\mathrm{ab}}$ \\
\hline & Moisture & $36^{\mathrm{b}}$ & $31^{\mathrm{a}}$ & $30^{\mathrm{a}}$ & $29^{\mathrm{a}}$ & $40^{c}$ & $37^{\mathrm{bc}}$ & $36^{\mathrm{b}}$ & $31^{\mathrm{a}}$ & $32^{\mathrm{a}}$ \\
\hline & Chewiness & $35^{b}$ & $44^{\mathrm{cd}}$ & $51^{\mathrm{e}}$ & $50^{\mathrm{e}}$ & $23^{\mathrm{a}}$ & $21^{\mathrm{a}}$ & $35^{\mathrm{b}}$ & $45^{\mathrm{d}}$ & $42^{\mathrm{c}}$ \\
\hline & Hardness & $45^{b}$ & $49^{\mathrm{bc}}$ & $52^{\mathrm{c}}$ & $50^{\mathrm{bc}}$ & $34^{\mathrm{a}}$ & $32^{\mathrm{a}}$ & $45^{\mathrm{b}}$ & $49^{\mathrm{bc}}$ & $46^{\mathrm{bc}}$ \\
\hline & Elasticity & $33^{\mathrm{a}}$ & $35^{\mathrm{a}}$ & $33^{\mathrm{a}}$ & $34^{\mathrm{a}}$ & $34^{\mathrm{a}}$ & $36^{\mathrm{a}}$ & $35^{\mathrm{a}}$ & $36^{\mathrm{a}}$ & $36^{\mathrm{a}}$ \\
\hline \multirow{4}{*}{ 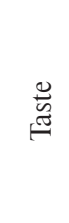 } & Typical & $52^{\mathrm{d}}$ & $47^{c}$ & $49^{\mathrm{cd}}$ & $47^{c}$ & $43^{\mathrm{b}}$ & $50^{\mathrm{cd}}$ & $52^{\mathrm{d}}$ & $36^{\mathrm{a}}$ & $42^{\mathrm{b}}$ \\
\hline & Flour & $36^{c}$ & $35^{\mathrm{bc}}$ & $40^{\mathrm{d}}$ & $33^{\mathrm{bc}}$ & $27^{\mathrm{a}}$ & $26^{\mathrm{a}}$ & $32^{\mathrm{b}}$ & $35^{\mathrm{bc}}$ & $32^{\mathrm{b}}$ \\
\hline & Fatty & $34^{\mathrm{e}}$ & $32^{\mathrm{de}}$ & $30^{\mathrm{cd}}$ & $27^{\mathrm{bc}}$ & $32^{\mathrm{de}}$ & $27^{\mathrm{bc}}$ & $26^{\mathrm{b}}$ & $25^{\mathrm{b}}$ & $19^{\mathrm{a}}$ \\
\hline & Foreign & $11^{\mathrm{b}}$ & $10^{\mathrm{b}}$ & $9^{a b}$ & $10^{\mathrm{b}}$ & $15^{\mathrm{c}}$ & $14^{\mathrm{c}}$ & $11^{\mathrm{b}}$ & $11^{\mathrm{b}}$ & $7^{\mathrm{a}}$ \\
\hline \multicolumn{2}{|c|}{ Overall quality } & $52^{\mathrm{b}}$ & $54^{\mathrm{bc}}$ & $52^{\mathrm{b}}$ & $48^{\mathrm{a}}$ & $58^{\mathrm{d}}$ & $58^{\mathrm{d}}$ & $51^{\mathrm{ab}}$ & $54^{\mathrm{bc}}$ & $57^{\mathrm{d}}$ \\
\hline
\end{tabular}

a-f - capital characters in each row mean statistically significant differences at $p \geq 0.05$.

The effect of inulin addition on sensory quality of the sponge-fatty products

Average results of the sensory evaluation of the products are given in Table 5.

The addition of inulin did not affect negatively the ability to detect the typical odor of fatty sponge-cake products. Fat-free samples showed the highest intensity of this feature. Furthermore, products with higher levels of inulin were characterized by a reduced intensity of foreign and flour odor. Products without the addition of inulin (control samples), regardless of the type of fat, showed the highest intensity of fatty odor.

The substitution of fat (of whatever type) by inulin had a positive impact on discriminants of appearance. The fat-free product was characterized by a homogenous crumb structure and color.

The addition of inulin also affected discriminants of products texture. Porosity of all products containing fat (HR), regardless of the amount of inulin addition, was evaluated at a similar level (from 41 to 44). Among the products with AK fat, considered to be the most porous, were the samples without any and with the lowest addition of inulin $(20 \mathrm{~g} / \mathrm{kg})$.

Increasing addition of inulin to the products with fat, according to the evaluators, reduced moisture of the cakes. Products without fat $(62.5 \mathrm{~g} / \mathrm{kg}$ inulin) were considered as medium porous and "dry', which did not confirm the results obtained using instrumental methods (Table 3). A larger inulin addition (above $35 \mathrm{~g} / \mathrm{kg}$ ) enhanced the products' chewiness, regardless of the fat type. Elasticity of the products was evaluated at a similar level, from 33 to 36, regardless of the variant.

In the case of batter including fat with a high content of TFA (HP), products without and with $35 \mathrm{~g} / \mathrm{kg}$ of inulin content had the most typical taste. The taste of products including fat with a low content of TFA (AK) and $20 \mathrm{~g} / \mathrm{kg}$ and $35 \mathrm{~g} / \mathrm{kg}$ addition of inulin was rated best. The typical taste was weakly recognizable in fat-free products.

On substitution of trans-free fat (AK), the lowest overall quality was noticed for products with $35 \mathrm{~g} / \mathrm{kg}$ addition of inulin and, in the case of HR elimination (a high content of TFA), for products with $50 \mathrm{~g} / \mathrm{kg}$ inulin.

Sensory properties were described by means of two principal components (PC1, PC2) explaining $74.46 \%$ of the discriminants variability (Figure $4 \mathrm{a}$ ). The first component was explained by $49.25 \%$ variables connected mainly to the taste and odor of the product (it was positively correlated with chewiness and flour taste and negatively with moisture, and oily odor, homogeneity of crumb, oily and foreign taste, and overall quality). The second component explained $25.21 \%$ of the variability and was strongly positively correlated with hardness and elasticity, and negatively with the typical odor.

Based on the PCA analysis of the sensory characteristics of the products (Figure 2b), it has been shown that products including fat with a high content of TFA (HR) were similar and exhibited the largest chewiness and flour taste. The samples with trans-free fat and with the lowest addition of inulin (AK 0, AK 2) were similar in respect of sensory quality (over- 

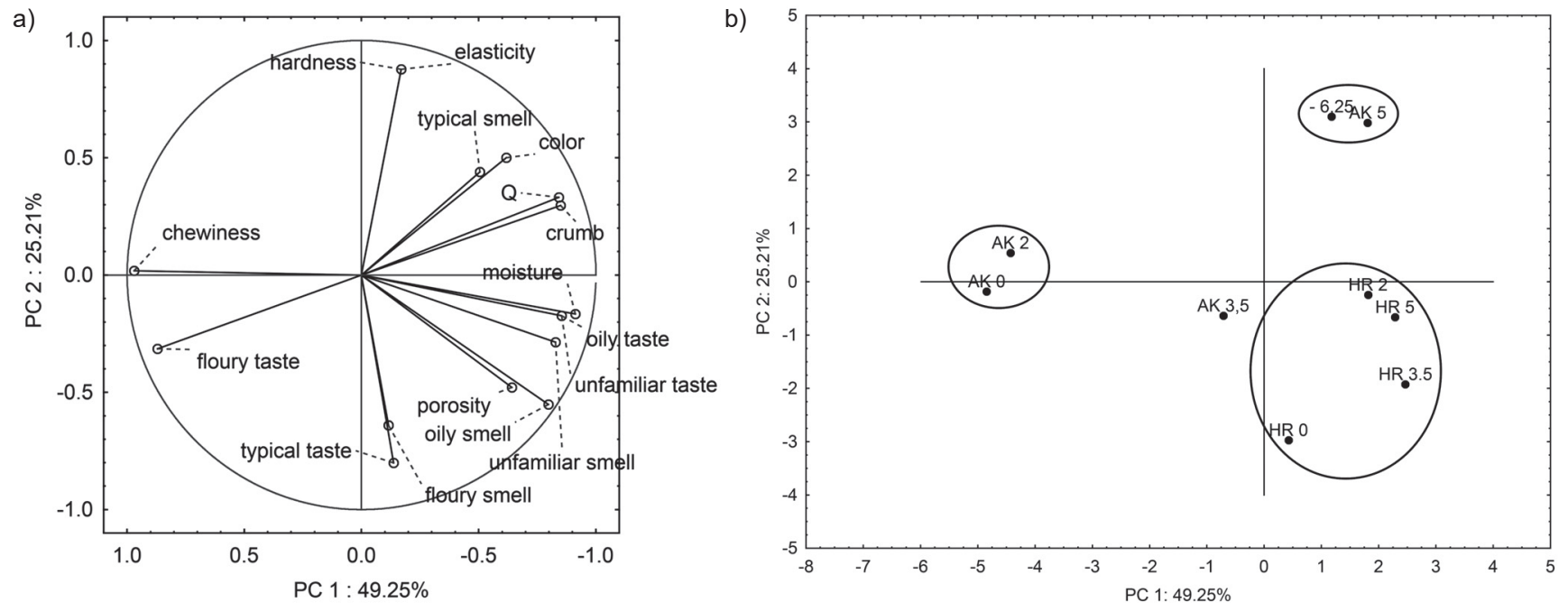

FIGURE 4. Result of the PCA analysis for sensory evaluation. Score plot in the plane of principal components: PC2 vs. PC1 for all samples. Crossed samples indicate similarity. ${ }^{*} \mathrm{Q}$ - overall sensory quality.

all quality, homogeneity of crumb, moisture, oily taste, foreign taste and odor), as well as in respect of physical parameters (Figure 2b). The principal component analysis revealed a similarity between fat-free products (-6.25) and products containing the largest addition of inulin based on trans-free fat (AK 5).

\section{DISCUSSION}

A partial substitution of fat with inulin did not significantly change the quality of the intermediate product, especially where fat with a high content of TFA was removed. A total elimination of fat from the recipe and its replacement with inulin improved aeration of the batter. It has been shown the fats held the air introduced to the pastry to varying degrees and it can be assumed that these differences were due to the composition of fatty acids in the fats used. Fats with a high solid content, characterized by a large number of small fat crystals with a high melting point, can stabilize air bubbles in the batter. On the other hand, too hard a fat can impede batter aeration [Brooker, 1996; Autio \& Laurikainen, 1997]. High contents of TFA and SFA provide a high melting point and a solid fat content [Żbikowska et al., 2012].

Reducing energetic value of the product, which traditionally contains large amounts of fat, is important in view of overweight and obesity, common in societies of developed countries [De Onis, 2010; Biro \& Wien, 2010]. In accordance with the recommendations of the Committee for Nutrition. the quantity of fat in the diet should be limited and TFA should be eliminated [EFSA, 2010]. The total elimination of fat in the tested products seriously reduced the energetic value (Table 2) and eliminated nutritionally-unfavorable fatty acids.

Regardless of the degree of fat substitution withy inulin and the type of fat, crumb of the products was characterized by good quality (Table 3). Ziobro et al. [2013] found that the addition of inulin increased bread volume and reduced bread crumb hardness. In contrast, Brasil et al. [2011] showed that only larger additions of inulin caused changes in volume and crumb porosity. The results obtained during our analysis differ depending on the type of fat. In the case of the fat with a high content of TFA (HR), the highest addition of inulin $(50 \mathrm{~g} / \mathrm{kg})$ was preferred. In the case of trans-free fat substitution (AK), the minimum addition of inulin $(20 \mathrm{~g} / \mathrm{kg})$ improved physical properties of fatty sponge-cake products (Table 3 ).

The addition of inulin caused an increase of water content in the products. Górecka et al. [2001] revealed a higher water content of confectionery products containing inulin. On the basis of PCA projection, a strong correlation was identified between moisture of fatty sponge-cake products and their cohesion and elasticity (Table 3 ).

Fat has a much greater influence on the texture of cakes than sugar or flour [Brasil et al., 2011; Zoulias et al., 2002]. Results obtained during our experiments showed that the level of fat substitution and its type affect the mechanical properties of the tested products. Increase of fat substitution with inulin boosted the maximum force required to cut the crumb of fatty sponge-cake samples and increased their hardness, cohesiveness and elasticity. Laguna et al. [2013] also found that the magnitude of the force depended on the type of fat replacer and on its concentration. The increase in the maximum force was greater when fat was replaced with inulin. Brasil et al. [2011] showed that adding $60 \mathrm{~g} / \mathrm{kg}$ inulin as a fat replacer did not significantly affect any of the attributes investigated, while a $100 \mathrm{~g} / \mathrm{kg}$ addition resulted in a significantly altered texture. In addition, Ziobro et al. [2013] also found that inulin diminished the rate of bread staling (measured as the rate of crumb hardening). The mechanical properties of the crumb of the analyzed fatty sponge-cake fat-free samples differed from those of the other samples. Smaller forces were needed to cut them than for the other products. These products were also characterized by a lower hardness and chewiness than the other samples analyzed.

Fat is an important factor influencing sensory properties of products. According to Górecka et al. [2001], the addition of 20 and $40 \mathrm{~g} / \mathrm{kg}$ of inulin, improved the sensory characteristics of bakery products. Taking into account discriminants of the sensory quality of fatty sponge-cake products discussed in this paper (Table 5), it can be concluded that the reduction 
of fat to $440 \mathrm{~g} / \mathrm{kg}$ in products including fat with a high content of TFA in relation to the control sample and the introduction of inulin $(35 \mathrm{~g} / \mathrm{kg})$ instead did not result in any significant changes of the overall quality of the products. However, in the case of products containing AK fat with a low content of TFA, its substitution with $320 \mathrm{~g} / \mathrm{kg}$ of inulin $(20 \mathrm{~g} / \mathrm{kg}$ of inulin in relation to the total mass of the sample) diminished the quality of products (Table 5). A cluster analysis and PCA of sensory quality discriminants revealed that the fresh bread prepared with inulin was clustered in the same group as the control sample and in the vicinity of the control on the PCA biplot [Polaki et al., 2010]. On the basis of statistical analysis (QDA), one can also state that adding $60 \mathrm{~g} / \mathrm{kg}$ of inulin as a fat replacer did not significantly affect any of the attributes investigated, while a $100 \mathrm{~g} / \mathrm{kg}$ addition resulted in significantly altered color of the crumb [Brasil et al., 2011]. Filipovic et al. [2010] said (using a scorecard system) that the addition of $50 \mathrm{~g} / \mathrm{kg}$ of inulin did not significantly reduce the sensory quality of bread crumb. However, according to Laguna et al. [2013], replacement of more than $150 \mathrm{~g} / \mathrm{kg}$ of fat with inulin causes deterioration of the sensory quality of biscuits, especially their texture. Previous studies also obtained acceptable scores for low fat biscuits. Seker et al. [2010] studied the sensory effect of apricot kernel flour in biscuits replacing up to $40 \mathrm{~g} / 100 \mathrm{~g}$ of fat and found acceptability scores that were not significantly different from the control. Based on Zoulias et al. [2002], it can be concluded that the overall quality declines if fat replacement in a biscuit formulation is higher than $50 \%$.

In the present study, fat-free products with $62.5 \mathrm{~g} / \mathrm{kg}$ addition of inulin were highly rated in terms of sensory quality (Table 5). However, it should be emphasized that the PCA has shown that they are not substantially similar to classic fatty sponge-cake products. Their physical features and sensory panel acceptance suggest that products with a reduced energetic value and without fatty acids trans isomers can be appreciated by consumers.

\section{CONCLUSIONS}

The results indicate the possibility of eliminating fat from fatty sponge-cake products by replacing it with inulin. This fat substitution allows eliminating adverse TFA, reducing energetic products' value, and simultaneously enriching them with nutritionally-valuable oligosaccharides. Products with reduced fat content and inulin addition were characterized by good crumb quality and were highly rated from the sensory point of view. On this basis, it can be concluded that inulin in the production of fatty sponge-cake products may perform the technological functions and at the same time increase the nutritional value. Furthermore, products without the addition of fat had porous, spongy structure and a high overall quality, and can therefore be an alternative to the conventional fatty sponge-cake products as a factor that supports prevention of many diseases and food-related disorders.

Results obtained during the experiments described in this paper look promising and it is worth proceeding further in this field. The scope of research will be extended by replacing fat with inulin in other bakery based products in order to make the products analyzed better suited to customer expectations.

\section{NOTE}

Neither human nor animal rights have been violated during experiments.

\section{RESEARCH FUNDING}

This work was supported by funds from Warsaw University of Life Sciences.

\section{CONFLICT OF INTEREST}

Authors declare no conflict of interest.

\section{REFERENCES}

1. Autio K., Laurikainen T., Relationships between flour/dough microstructure and dough handling and baking properties. Trends Food Sci. Tech., 1997, 8, 181-185.

2. Barylko-Pikielna N., Matuszewska I., Sensory analysis of food. Basics-Methods - Application. 2009, PTTZ Publishing, Krakow (in Polish).

3. Bendsen N.T., Christensen R., Bartels E.M., Astrup A., Consumption of industrial and ruminant trans fatty acids and risk of coronary heart disease: a systematic review and meta-analysis of cohort studies. Eur. J. Clin. Nutr., 2011, 65, 773-783.

4. Biro F.M., Wien M., Childhood obesity and adult morbidities. Am. J. Clin. Nutr., 2010, 91, 1499S-1505S.

5. Blonska A., Marzec A., Błaszczyk A., Instrumental evaluation of acoustic and mechanical texture properties of short dough biscuits with different content of fat and inulin. J. Texture Stud., 2014, 45, 226-234.

6. Brasil J.A., da Silveira K.C., Salgado S.M., Souza Livera A.V., de Faro Z.P., Guerra N.B., Effect of the addition of inulin on the nutritional, physical and sensory parameters of bread. Braz. J. Pharm. Sci., 2011, 47, 185-191.

7. Brennan C.S., Kuri V., Tudorica C.M., Inulin-enriched pasta: effects on textural properties and starch degradation. Food Chem., 2004, 86, 189-193.

8. Brooker B.E., The role of fats in the stabilization of gas cells in bread dough. J. Cereal Sci., 1996, 24, 187-198.

9. Cieslak E., Gebusia A., Functional foods with glucans added. Zywn. Nauk. Technol. Ja., 2011, 2, 27-37 (in Polish; English abstract).

10. Coussement P.A.A., Inulin and oligofructose: safe intake and legal status. J. Nutr., 1999, 129, 1412S-1417.

11. De Onis M., Blossner M., Borghi E., Global prevalence and trends of overweight and obesity among preschool children. Am. J. Clin. Nutr., 2010, 92, 1257-64.

12. EFSA, Scientific Opinion on Dietary Reference Values for fats, including saturated fatty acids, polyunsaturated fatty acids, monounsaturated fatty acids, trans fatty acids, and cholesterol. The EFSA Journal, 2010, 1461, 1-107.

13. Filipovic J., Filipovic N., Filipovic V., The effects of commercial fibres on frozen bread dough. J. Serb. Chem. Soc., 2010, 75, 195-207.

14. Gorecka A., Butka A., Korczak J., The effect of inulin addition on the quality of confectionery products. Zywn. Nauk. Technol. Ja., 2001, 28, 125-135 (in Polish; English abstract). 
15. Grabitske H.A., Slavin J.L., Gastrointestinal effects of low-digestible carbohydrates. Crit. Rev. Food Sci., 2009, 49, 327-360.

16. Hadorn R., Piccinali P., Suter M., Fat reduction with inulin in water-boiled sausages. Rev. Suisse Agric., 2007, 39, 244-248.

17. Hennelly P.J., Dunne P.G., O'Sullivan M., O'Riordan E.D., Textural rheological and microstructural properties of imitation cheese containing inulin. J. Food Eng., 2006, 75, 388-395.

18. Horubalowa A., Analiza pieczywa. 1983 in: The Analysis of Cereals and Cereal Products (ed. T. Jakubczyk, T. Haber). SGGWAR Publishing, Warszawa (in Polish).

19. ISO 2003. Sensory analysis. Methodology. General guidance for establishing a sensory profile.

20. James W.P., The epidemiology of obesity: the size of the problem. J. Intern. Med., 2008, 263, 336-352.

21. Kip P., Meyer D., Jellema R.H., Inulins improve sensoric and textural properties of low-fat yoghurts. Intern. Dairy J., 2006, 16, 1098-1103.

22. Kunachowicz H., Przygoda B., Nadolna I., Iwanow K., Tables of Nutritional Value and Composition of Food. 2005, Wydawnictwo Lekarskie PZWL, Warszawa (in Polish).

23. Laguna L., Primo-Martín C., Varela P., Salvador A., Sanz T., HPMC and inulin as fat replacers in biscuits: Sensory and instrumental evaluation. LWT - Food Sci. Technol., 2013, 30, 1-8.

24. Marciniak-Lukasiak K., The role and significance of omega 3 fatty acids. Zywn. Nauk. Technol. Ja., 2011, 6, 24-35 (in Polish; English abstract).

25. Morris C., Morris G.A., The effect of inulin and fructo-oligosaccharide supplementation on the textural, rheological and sensory properties of bread and their role in weight management: A review. Food Chem., 2012, 133, 237-248.

26. Polaki A., Xasapis P., Fasseas C., Yanniotis S., Mandala I., Fiber and hydrocolloid content affect the microstructural and sensory characteristics of fresh and frozen stored bread. J. Food Eng., 2010, 97, 1-7.

27. Rahmati N.F., Mazaheri M., Tehrani M., Influence of different emulsifiers on characteristics of eggless cake containing soy milk: Modeling of physical and sensory properties by mixture experimental design. J. Food Sci. Tech., 2014, 51, 1697-1710.

28. Rutkowska J., Zbikowska A., Effects of fatty acids composition of liquid margarines on sensory quality of cakes. Acta Alimen. Hung., 2010, 39, 136-148.

29. Seker I.T., Ozboy-Ozbas O., Ozturk S., Koksel H., Utilization of apricot kernel flour as fat replacer in cookies. J. Food Process. Pres., 2010, 34, 15-26.

30. Surmacka-Szczesniak A., Classification of textural characteristics. J. Food Sci., 1963, 28, 385-386.

31. WHO, 2010, [http://www.who.int/mediacentre/factsheets/fs311/en/].

32. Ziobro R., Korus J., Juszczak J., Witczak T., Influence of inulin on physical characteristics and staling rate of gluten-free bread. J. Food Eng., 2013, 116, 21-27.

33. Zoulias E.I., Oreopoulou V., Kounalaki E., Effect of fat and sugar replacement on cookie properties. J. Sci. Food Agri., 2002, 82, $1637-1644$.

34. Żbikowska A., Kowalska M., Rutkowska J., Solid fat content versus quality and technological usefulness of shortenings in making shortcrust pastries. Zywn. Nauk. Technol Ja., 2012, 2, 173-185 (in Polish; English abstract).

35. Żbikowska A., Formation and properties of trans fatty acids a review. Pol. J. Food Nutr. Sci., 2010, 60, 107-114.

Submitted: 24 November 2015. Revised: 10 April 2016. Accepted: 5 July 2016. Published on-line: 28 November 2016. 
